\title{
THE CONSTRUCTION OF PUBLIC POLICIES IN THE FIELD OF CHILD AND JUVENILE MENTAL HEALTH IN BRAZIL: HISTORICAL TRAJECTORY AND CONTEMPORARY PROBLEMS
}

Walter Bahia, Leonardo Ramos Pereira, Daniel Carvalho Rocha, Valdir Pierote Silva Centro de Atenção Psicossocial II Infanto-Juvenil FÓ/Brasilândia, São Paulo (SP), Brazil

The formation of Brazil is marked by a large history of violence and authoritarism, characteristics that have marked the last century, specially during two important dictatorship periods (1937-1945 e 1964-1985). In these two occasions various attempts against human dignity have been perpetrated. In this context, psychiatric hospitals have served as "depots and annihilation engines" of subjects that caused discomfort to society, including children and adolescents. To combat this situation several social groups created the Brazilian Anti-asylum Movement, what have established the foundation for the Brazilian Pyschiatric Reform. During the same period, historical and legal landmarks were established: (1) the 1988 Brazilian Federal Constitution, which defined health as a universal right; (2) the 1990 Child and Adolescent Statute, a set of laws that established the rights of children and adolescents in Brazil; (3) the 2010 Federal Law 10.216, which instituted a new model of mental health care based on guaranteeing the rights of people with mental disorders, and created the Psychosocial Care Centers, community institutions with free treatment, as articulators of mental health care connected to the population.

Despite advances in the legislation in February 2019, the Bolsonaro Government published Technical Note 11/2019 to present "clarifications on changes to the National Mental Health Policy and the National Drug Policy Guidelines [...] with the aim to organize the treatment and assistance to patients and their families [...] "2. It is a set of guidelines and propositions, compiling changes made during the Temer Government (2016-2018), besides of adding new directions.

The repercussion of this document was very negative and, a few days after its publication, the note was removed from the Ministry of Health website, losing some official character and operating as a phantom, menacing to update itself in new realities at each government action.

The most critical point is the inclusion at RAPS (Psychosocial Care Network) of the Specialized Psychiatric Hospital. In practice, the Ministry of Health promotes the incentive of large-scale and longterm psychiatric hospitals by creating financial

1. DELGADO, P. Saúde Mental e Direitos Humanos: 10 anos da Lei $10.216 /$ 2001. Arquivos Brasileiros de Psicologia. Rio de Janeiro, v. 63, n. 2, p. 114121, 2011.

2. BRASIL. Ministério da Saúde. Nota Técnica 11/2019. Esclarecimentos sobre as mudanças na Política Nacional de Saúde Mental e nas Diretrizes na Política Nacional sobre Drogas. Coordenação Nacional de Saúde Mental, Álcool e Outras Drogas. 2019. Disponível em:<https://www.abrasco.org.br/site/wp-

content/uploads/2019/02/11 $2314 \quad 123$ Nota Te\%CC\%81cnica no.11 201 9 Esclarecimentos sobre as mudanc\%CC $\%$ A7as da Politica de Sau $\% \mathrm{C}$ C\%81de Mental.pdf>. Acesso em: 18 mar. 2019

3. World Health Organization (WHO). Mental Health Action Plan 2013-2020. Geneva: WHO; 2013. p. 15-16.

Scenes from the movie "Em nome da razão" (1979), directed by Helvécio Ratton (Quimera Filmes) arrangements that provides the payment of more than 400 beds and readjustment of the daily rates for hospitalizations above 90 days. In the document, the Ministry also states that "there is no legal impediment to hospitalization of underaged patients in Psychiatric Wards."

The recommendations of Technical Note 11/2019 go in the opposite direction from the recommendations of the World Health Organization, which in its Mental Health Action Plan 2013-2020 points out as guidelines:

Systematically shift the locus of care away from long-stay mental hospitals towards non-specialized health settings with increasing coverage of evidence-based interventions (including the use of stepped care principles, as appropriate) for priority conditions and using a network of linked community-based mental health services, including short-stay inpatient care, and outpatient care in general hospitals, primary care, comprehensive mental health centres, day care centres, support of people with mental disorders living with their families, and supported housing. [...] Children and adolescents with mental disorders should be provided with early intervention through evidence-based psychosocial and other nonpharmacological interventions based in the community, avoiding institutionalization and medicalization. Furthermore, interventions should respect the rights of children in line with the United Nations Convention on the Rights of the Child and other international and regional human rights instruments ${ }^{3}$.

In this sense, major challenges are presented in the field of mental health in Brazil and in guaranteeing the rights of the populations served. Noteworthy are the attempts to deconstruct the Brazilian Psychiatric Reform, either with the reintroduction of hospitalizations in psychiatric hospitals, or with support for practices without evidence.

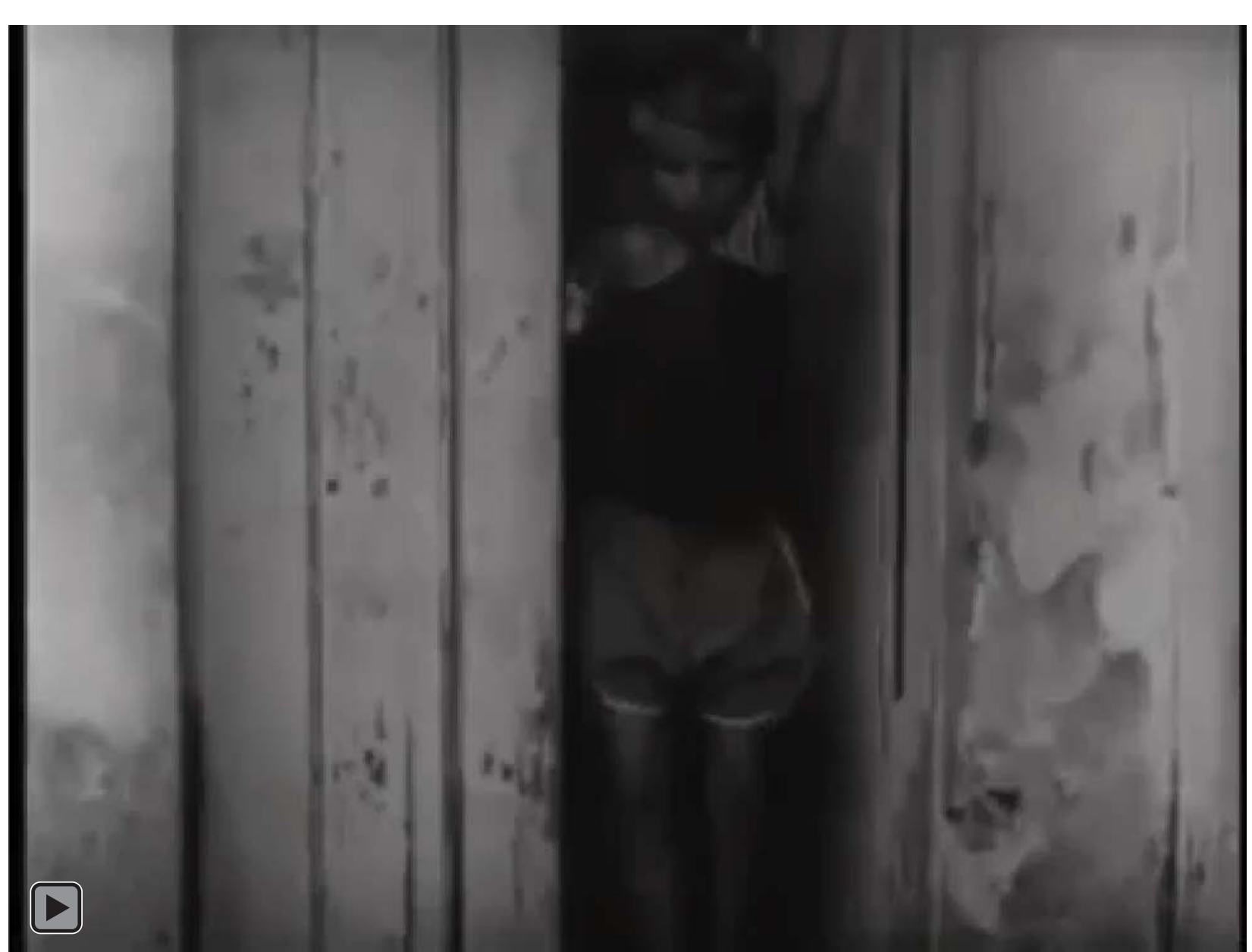

